\title{
Latent viruses can cause disease by disrupting the competition for the limiting factor p300/CBP
}

\author{
Hanan Polansky ${ }^{*}$ (D) and Hava Schwab
}

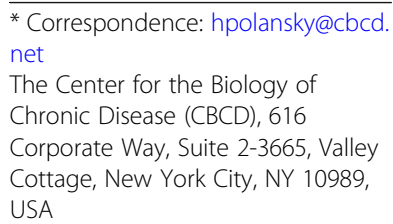

* Correspondence: hpolansky@cbcd. net

The Center for the Biology of Chronic Disease (CBCD), 616 Corporate Way, Suite 2-3665, Valley Cottage, New York City, NY 10989, USA

\begin{abstract}
CBP and p300 are histone acetyltransferase coactivators that control the transcription of numerous genes in humans, viruses, and other organisms. Although two separate genes encode CBP and p300, they share a 61\% sequence identity, and they are often mentioned together as p300/CBP. Zhou et al. showed that under hypoxic conditions, HIF1a and the tumor suppressor p53 compete for binding to the limiting p300/CBP coactivator. Jethanandani \& Kramer showed that $\delta E F 1$ and MYOD genes compete for the limited amount of p300/CBP in the cell. Bhattacharyya et al. showed that the limiting availability of p300/CBP in the cell serves as a checkpoint for HIF1 a activity. Here, we use the microcompetition model to explain how latent viruses with a specific viral cis-regulatory element in their promoter/enhancer can disrupt this competition, causing diseases such as cancer, diabetes, atherosclerosis, and obesity.
\end{abstract}

Keywords: $\delta E F 1$, MYOD, HIF1a, p53, CBP, p300, Limiting, Microcompetition, Transcription factor

With at least 315 different cellular and viral interacting proteins, CBP and p300 are considered the most heavily connected coactivators in the mammalian protein-protein interaction network $[1,2]$. Both are histone acetyltransferases, and they control the transcription of numerous genes in humans, viruses, and other organisms. Although two separate genes encode CBP and p300, they share a $61 \%$ sequence identity, and they are often mentioned together as $\mathrm{p} 300 / \mathrm{CBP}$ [3].

p300/CBP is a $300-k D a$ protein that has a $\mathrm{CH} 2$ domain, which contains its acetyltransferase activity, and five protein-binding domains [3]. Many studies have shown that competition for the limiting $\mathrm{p} 300 / \mathrm{CBP}$ is an important mechanism that regulates transcription and cellular activities. This commentary discusses three of these studies [4-6] and connects their observations to the microcompetition model [7, 8].

Using differential equations and a dimensionless state variable, Zhou et al. [5] determined the effect of p300 on the steady-state concentrations of proteins. They discovered that under hypoxic conditions, HIF1 $\alpha$ and the tumor suppressor p53 compete for binding to the coactivator p300. They showed that p300 is required for full transcriptional activity of both p53 and HIF1 $\alpha$. According to Zhou et al., this competition indicates that $\mathrm{p} 300$ is limiting.

The $\alpha 7$ integrin is involved in the differentiation of myoblasts and is negatively regulated by $\delta \mathrm{EF} 1$, a zinc finger transcription factor, and positively regulated by MYOD. $\delta \mathrm{EF} 1$

(C) The Author(s). 2018 Open Access This article is distributed under the terms of the Creative Commons Attribution 4.0 International License (http://creativecommons.org/licenses/by/4.0/), which permits unrestricted use, distribution, and reproduction in any medium, provided you give appropriate credit to the original author(s) and the source, provide a link to the Creative Commons license, and indicate if changes were made. The Creative Commons Public Domain Dedication waiver (http://creativecommons.org/ publicdomain/zero/1.0/) applies to the data made available in this article, unless otherwise stated. 
has an NR (negative region) domain that binds the p300/CBP coactivator. Overexpression of $\delta E F 1$ inhibits muscle cell differentiation and represses the activation of the muscle creatine kinase enhancer. On the other hand, MYOD activates muscle genes by binding p300, and uses p300/CBP histone acetylase activity to allow for transcription [4].

Jethanandani \& Kramer [4] transfected C2C12 cells with the p400 fragment of the $\alpha 7$ integrin promoter. Then, they co-transfected the cells with either $\delta \mathrm{EF} 1$ alone, $\delta \mathrm{EF} 1$ and MYOD, or $\delta \mathrm{EF} 1$ and CBP, and measured the CAT reporter activity. They observed that CBP increased CAT activity, i.e., an increase in CBP levels mitigated the repression of $\alpha 7$ by $\delta E F 1$. Based on their results, Jethanandani \& Kramer concluded that p300/CBP is limiting, and that $\delta E F 1$ competes with MYOD for the limited amounts of p300/CBP in the cell.

Bhattacharyya et al. [6] infected human gastric epithelium cells with Helicobacter pylori. The results showed an increase in transcription complex formation at the HREs (hypoxia-response elements) of the mcl1 promoter. Then, they observed that the complex included p300, HIF1 $\alpha$, and APE1 (apurinic/apyrimidinic endonuclease 1). Western blotting on whole cell lysates from AGS cells showed that the binding of p300 to the hif $1 \alpha$ promoter decreased at higher levels of $H$. pylori infection, without a decrease in the p300 concentration. Moreover, they found that higher levels of H. pylori infection increased the expression of hif $1 \alpha$, but decreased the expression of the mcl 1 promoter, which is transactivated by HIF $\alpha$. They discovered that at higher H. pylori levels, HIF1 $\alpha$ binds to the HIF-binding site (HBS) on the hif1 $\alpha$ promoter. Since the HBS is transcriptionally inactive (it lacks the required HIF ancillary sequence, denoted as HAS), this binding does not further transactivate the hif $1 \alpha$ promoter. However, this binding has a sequestering effect that limits the intracellular availability of the HIF $1 \alpha \cdot p 300$ complex to the mcl1 gene, which decreases mcl1 expression.

The observations in the Bhattacharyya et al. study indicate that p300 is limiting, meaning the HIF1 $\alpha \cdot p 300$ complex is limiting. They also show that the decrease in HIF $1 \alpha \cdot$ p300 binding to the mcl1 promoter, which decreases mcl1 transcription, is due to competition for the limiting HIF $1 \alpha \cdot p 300$ by the hif1 $\alpha$ promoter itself. Based on their observations, Bhattacharyya et al. concluded that the limiting availability of p300 in the cell is a checkpoint for HIF1 $\alpha$ activity.

These studies showed that competition between cellular transcription factors to bind the limiting p300/CBP is an important regulator of transcription. According to the microcompetition model, disrupting this regulation causes many diseases. The microcompetition model was first described in the book Microcompetition with Foreign DNA and the Origin of Chronic Disease [7, 8]. It centers on one type of disruption of this regulation: the one caused by the viruses with an N-box, which is a strong cis-regulatory element found on their promoters/enhancers. During the latent phase, this element binds the cellular GABP•p300/CBP transcription complex, which is limiting, because p300/CBP is limiting. Therefore, the viral N-boxes decrease the availability of GABP•p300/CBP in the cell. The result is abnormal expression of the cellular genes that bind GABP•p300/CBP. The genes that are transactivated by the GABP•p300/CBP complex synthesize fewer proteins, while those that are transrepressed by the complex synthesize more proteins. The abnormal levels of these cellular proteins can cause disease, such as cancer, diabetes, atherosclerosis, and obesity. The book lists human genes that bind the GABP•p300/CBP complex (Table 1) and presents supporting evidence to show that these genes express abnormal levels of their proteins in these diseases. 
Table 1 List of some human genes that bind the GABP·p300/CBP transcription complex

\begin{tabular}{ll}
\hline Gene & Reference \\
\hline B2 leukocyte integrin (CD18) & Rosmarin et al. 1998 [22] \\
Interleukin 16 (IL-16) & Bannert et al. 1999 [23] \\
Interleukin 2 (IL-2) & Avots et al. 1997 [24] \\
Interleukin 2 receptor $\beta$-chain (IL-2Rß) & Lin et al. 1993 [25] \\
IL-2 receptor $\gamma$-chain (IL-2 $\gamma C)$ & Markiewicz et al. 1996 [26] \\
Human secretory interleukin-1 receptor & Smith et al. 1998 [27] \\
antagonist (secretory IL-1 ra) & \\
Retinoblastoma (Rb) & Sowa et al. 1997 [28] \\
Human thrombopoietin (TPO) & Kamura et al. 1997 [29] \\
Aldose reductase & Wang et al. 1993 [30] \\
Neutrophil elastase (NE) & Nuchprayoon et al. 1999 [31], \\
Folate binding protein (FBP) & Nuchprayoon et al. 1997 [32] \\
Cytochrome c oxidase subunit Vb (COXVb) & Sadasivan et al. 1994 [33] \\
Cytochrome c oxidase subunit IV & Basu et al. 1993 [34], \\
Mitochondrial transcription factor A (mtTFA) & Sucharov et al. 1995 [35] \\
$\beta$ subunit of the FoF1 ATP synthase (ATPsyn $\beta$ ) & Carter et al. 1994 [36], \\
Prolactin (PRL) & Carter et al. 1992 [37] \\
Oxytocin receptor (OTR) & Virbasius et al. 1994 [38] \\
\hline & Villena et al. 1998 [39] \\
\hline & Ouyang et al. 1996 [40] \\
\hline & Hoare et al. 1999 [41] \\
\hline
\end{tabular}

Some common viruses with an N-box are the cytomegalovirus (CMV), Epstein-Barr virus (EBV), herpes simplex virus 1 (HSV-1), human T-cell lymphotropic virus (HTLV), and human immunodeficiency virus (HIV). These viruses are highly prevalent. For instance, an estimated 3.7 billion people worldwide, or around $67 \%$ of the global population, are infected with HSV-1 [9]. Since the virus is highly prevalent, why do only a fraction of infected people develop the disease? The answer is that the copy number during latency matters. Only a high enough copy number produces the strong enough sequestering effect that causes a disease (Fig. 1).

A recent paper by Zuo et al. [10] showed that the copy number of latent EBV, a virus that binds GABP•p300/CBP during latency, is strongly associated with oncogenicity $[11,12]$. What determines the copy number of a virus during its latent phase? It is well known that there is a balance between the efficiency of the immune system and the copy number of latent viruses. It is also known that many events can cause immunodeficiency, including aging [13], certain medications [14, 15], surgery [16-18], chemotherapy [19], radiation [20], and stress [21]. Such events decrease the efficiency of the immune system, increasing the copy number of latent viruses and the risk of disease, as observed by Zuo et al., who stated:

"It has been noticed that EBV load in tumor tissues or blood is associated with the clinical progression and prognosis in both lymphoma and NPC. Our result verifies this association. We also emphasize the importance to measure the level of gene expression or copy number in the virus study instead of only concerning 'with and without'." 

A. Immunodeficiency due to stress, aging, disease, etc.

B. More copies of the latent virus

\section{More GABP•p300/CBP complexes bind the viral promoters}

D. Fewer GABP•p300/CBP complexes bind the promoter of the cellular gene

E. Lower or higher expression of cellular genes

\section{F. Disease}
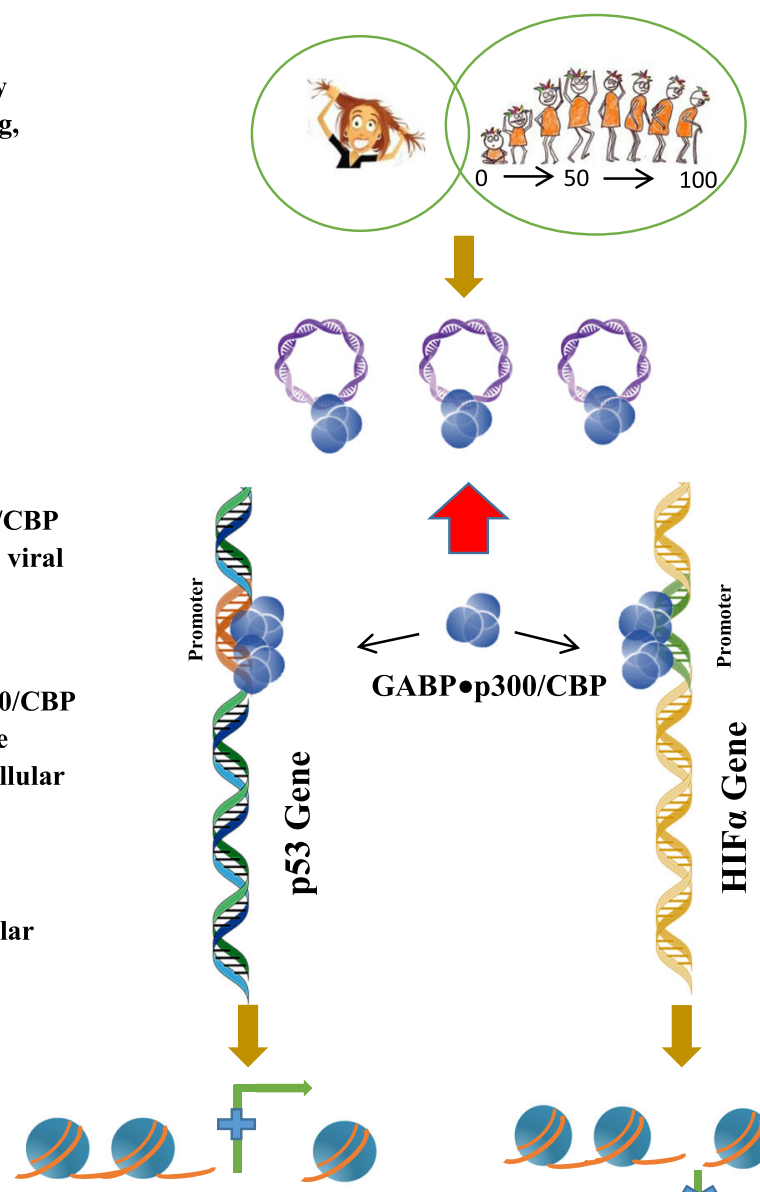

GABP•p300/CBP

Gene "1"
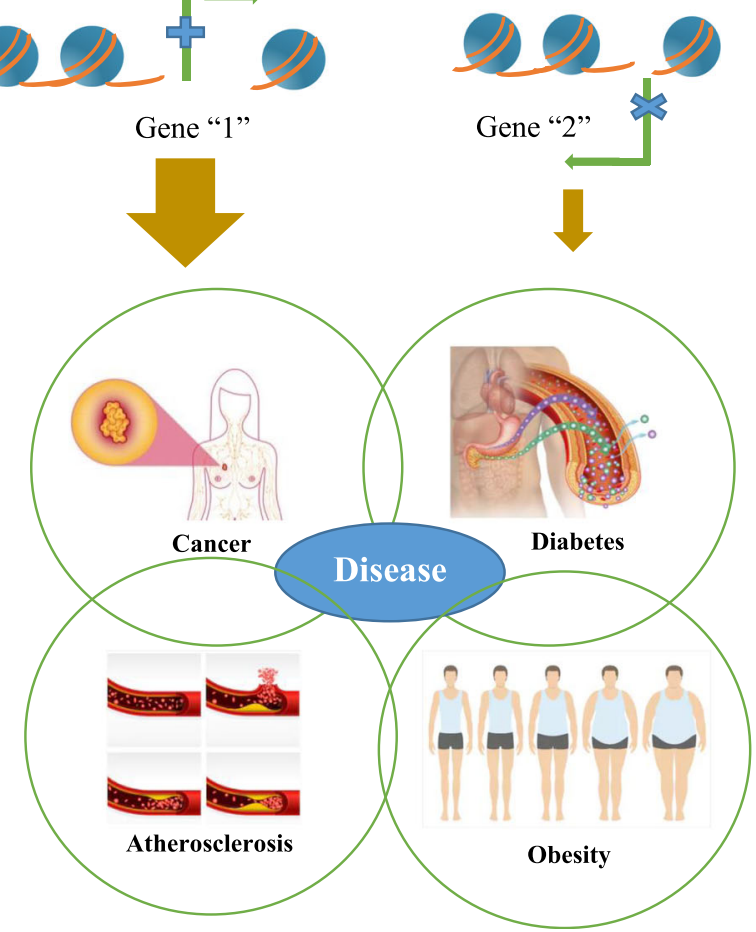

Fig. 1 Latent viruses, the microcompetition model, and disease. a Immunodeficiency occurs due to stress, aging, disease, etc. $\mathbf{b}$ More copies of the latent virus are present in the system $\mathbf{c}$ Due to the increase in the copies of latent viruses, more GABP.p300/CBP complexes bind the viral promoters. $\mathbf{d}$ As a result, fewer GABP.p300/CBP complexes are available to bind the promoter of the cellular gene. e A lower or higher expression of cellular genes. $\mathbf{f}$ Disease occurs 
Our interpretation of the microcompetition model agrees with that of Zuo et al. It is the copy number of the viruses that sequester the limiting GABP•p300/CBP transcription complex and not the 'infected or not infected' that determines the fate of the infected individual. Therefore, it should be measured in clinical practice.

To conclude, the microcompetition model explains how an increase in the copy number of a latent virus that binds the limiting GABP•p300/CBP transcription complex increases the sequestering of the complex. This disrupts the allocation of the complex to cellular genes that compete to bind the complex. When this disruption is large enough, the host develops a disease.

Acknowledgements
Not applicable
Funding
The authors have no funding to declare.

Availability of data and materials

Not applicable

Authors' contributions

Both authors contributed equally to the article. Both authors read and approved the final manuscript.

Ethics approval and consent to participate

Not applicable

Consent for publication

Both authors consent to the publication of the article.

Competing interests

The authors declare that they have no competing interests.

\section{Publisher's Note}

Springer Nature remains neutral with regard to jurisdictional claims in published maps and institutional affiliations.

Received: 7 August 2018 Accepted: 7 November 2018

Published online: 26 November 2018

References

1. Rual J, Venkatesan K, Hao T, et al. Towards a proteome-scale map of the human protein-protein interaction network. Nature. 2005;437(7062):1173-8. https://doi.org/10.1038/nature04209.

2. Kasper L, Fukuyama T, Biesen $\mathrm{M}$, et al. Conditional knockout mice reveal distinct functions for the global transcriptional coactivators CBP and p300 in T-cell development. Mol Cell Biol. 2006;26(3):789-809. https://doi.org/10.1128/mcb.26.3. 789-809.2006.

3. Kasper L, Brindle P. Mammalian gene expression program resiliency: the roles of multiple coactivator mechanisms in hypoxia-responsive transcription. Cell Cycle. 2005:5(2):142-6. https://doi.org/10.4161/cc.5.2.2353.

4. Jethanandani P, Kramer R. a7 integrin expression is negatively regulated by $\delta E F 1$ during skeletal Myogenesis. J Biol Chem. 2005;280(43):36037-46. https://doi.org/10.1074/jbc.m508698200.

5. Zhou C, Zhang X, Liu F, Wang W. Modeling the interplay between the HIF-1 and p53 pathways in hypoxia. Sci Rep. 2015;5(1). https://doi.org/10.1038/srep13834.

6. Bhattacharyya A, Chattopadhyay R, Hall E, Mebrahtu S, Ernst P, Crowe S. Mechanism of hypoxia-inducible factor 1amediated Mcl1 regulation in helicobacter pylori-infected human gastric epithelium. Am J Physiol Gastrointest Liver Physiol. 2010;299(5):G1177-86. https://doi.org/10.1152/ajpgi.00372.2010.

7. Polansky H. Microcompetition with Foreign DNA and the Origin of Chronic Disease. Rochester, NY: CBCD Publishing; 2003.

8. Polansky H, Javaherian A. 3-Econsystems: MicroRNAs, receptors, and latent viruses; some insights biology can gain from economic theory. Front Microbiol. 2016;7:369. https://doi.org/10.3389/fmicb.2016.00369.

9. Herpes simplex virus. World Health Organization. http://www.who.int/en/news-room/fact-sheets/detail/herpes-simplexvirus. Published 2018. Accessed August 27, 2018.

10. Zuo L, Yu H, Liu L, et al. The copy number of Epstein-Barr virus latent genome correlates with the oncogenicity by the activation level of LMP1 and NF-KB. Oncotarget. 2015;6(38):41033-44.

11. Polansky H, Schwab H. Copy number of latent viruses, oncogenicity, and the microcompetition model. Oncotarget. 2018;9(60). https://doi.org/10.18632/oncotarget.25804.

12. Zuo L, Du S, Liu L, Lu J. The oncogenicity of Epstein-Barr virus: being "more or less" is to be concerned. Can Cell Microenviron. 2016;3:e1300. https://doi.org/10.14800/ccm.1300.

13. Castelo-Branco C, Soveral I. The immune system and aging: a review. Gynecol Endocrinol. 2014;30:16-22. https://doi.org/ 10.3109/09513590.2013.852531. 
14. Beghi E, Shorvon S. Antiepileptic drugs and the immune system. Epilepsia. 2011;52(Suppl 3):40-4. https://doi.org/10. 1111/j.1528-1167.2011.03035.x.

15. Røge R, Møller BK, Andersen CR, Correll CU, Nielsen J. Immunomodulatory effects of clozapine and their clinical implications: what have we learned so far? Schizophr Res. 2012;140:204-13. https://doi.org/10.1016/j.schres.2012.06.020.

16. Decker D, Tolba R, Springer W, Lauschke H, Hirner A, von Ruecker A. Abdominal surgical interventions: local and systemic consequences for the immune system--a prospective study on elective gastrointestinal surgery. J Surg Res. 2005;126:12-8. https://doi.org/10.1016/j.jss.2005.01.006.

17. Brøchner AC, Mikkelsen S, Hegelund I, Hokland M, Mogensen O, Toft P. The immune response is affected for at least three weeks after extensive surgery for ovarian cancer. Dan Med J. 2016;63.

18. Angka L, Khan ST, Kilgour MK, Xu R, Kennedy MA, Auer RC. Dysfunctional natural killer cells in the aftermath of Cancer surgery. Int J Mol Sci. 2017. https://doi.org/10.3390/ijms18081787.

19. Ghiringhelli F, Apetoh L. The interplay between the immune system and chemotherapy: emerging methods for optimizing therapy. Expert Rev Clin Immunol. 2014;10:19-30. https://doi.org/10.1586/1744666X.2014.865520.

20. Gaipl US. Modulation of the immune system by ionizing irradiation and chemotherapeutic agents - contribution of immune activation and blocking of immune suppression to cancer therapy success. Curr Med Chem. 2012;19:1739-40.

21. Vitlic A, Lord JM, Phillips AC. Stress, ageing and their influence on functional, cellular and molecular aspects of the immune system. Age (Dordr). 2014:36:9631. https://doi.org/10.1007/s11357-014-9631-6.

22. Rosmarin AG, Luo M, Caprio DG, Shang J, Simkevich CP. Sp1 cooperates with the ets transcription factor, GABP, to activate the CD18 (beta2 leukocyte integrin) promoter. J Biol Chem. 1998;273:13097-103.

23. Bannert R, Avots A, Baier M, Serfling E, Kurth R. GA-binding protein factors, in concert with the coactivator CREB binding protein/ p300, control the induction of the interleukin 16 promoter in T lymphocytes. Proc Natl Acad Sci U S A. 1999:96:1541-6.

24. Avots A, Hoffmeyer A, Flory E, Cimanis A, Rapp UR, Serfling E. GABP factors bind to a distal interleukin 2 (IL-2) enhancer and contribute to c-Rafmediated increase in IL-2 induction. Mol Cell Biol. 1997;17:4381-9.

25. Lin JX, Bhat NK, John S, Queale WS, Leonard WJ. Characterization of the human interleukin-2 receptor beta-chain gene promoter: regulation of promoter activity by ets gene products. Mol Cell Biol. 1993;13:6201-10.

26. Markiewicz S, Bosselut R, Le Deist F, de Villartay JP, Hivroz C, Ghysdael J, Fischer A, de Saint Basile G. Tissue-specific activity of the gammac chain gene promoter depends upon an Ets binding site and is regulated by GA-binding protein. J Biol Chem. 1996;271:14849-55.

27. Smith MF Jr, Carl VS, Lodie T, Fenton MJ. Secretory interleukin-1 receptor antagonist gene expression requires both a PU.1 and a novel composite NF-kappaB/PU.1/ GA-binding protein binding site. J Biol Chem. 1998;273:24272-9.

28. Sowa Y, Shiio Y, Fujita T, Matsumoto T, Okuyama Y, Kato D, Inoue J, Sawada J, Goto M, Watanabe H, Handa H, Sakai T. Retinoblastoma binding factor 1 site in the core promoter region of the human RB gene is activated by hGABP/E4TF1. Cancer Res. 1997:57:3145-8.

29. Kamura T, Handa H, Hamasaki N, Kitajima S. Characterization of the human thrombopoietin gene promoter. A possible role of an Ets transcription factor, E4TF1/GABP. J Biol Chem. 1997;272(17):11361-8.

30. Wang K, Bohren KM, Gabbay KH. Characterization of the human aldose reductase gene promoter. J Biol Chem. 1993:268:16052-8

31. Nuchprayoon I, Shang J, Simkevich CP, Luo M, Rosmarin AG, Friedman AD. An enhancer located between the neutrophil elastase and proteinase 3 promoters is activated by Sp1 and an Ets factor. J Biol Chem. 1999;274:1085-91.

32. Nuchprayoon I, Simkevich CP, Luo M, Friedman AD. Rosmarin AG. GABP cooperates with c-Myb and C/EBP to activate the neutrophil elastase promoter. Blood. 1997;89:4546-54.

33. Sadasivan E, Cedeno MM, Rothenberg SP. Characterization of the gene encoding a folate-binding protein expressed in human placenta. Identification of promoter activity in a G-rich SP1 site linked with the tandemly repeated GGAAG motif for the ets encoded GA-binding protein. J Biol Chem. 1994;269:4725-35.

34. Basu A, Park K, Atchison ML, Carter RS, Avadhani NG. Identification of a transcriptional initiator element in the cytochrome c oxidase subunit Vb promoter which binds to transcription factors NF-E1 (YY-1, delta) and Sp1. J Biol Chem. 1993;268:4188-96.

35. Sucharov C, Basu A, Carter RS. Avadhani NG. A novel transcriptional initiator activity of the GABP factor binding ets sequence repeat from the murine cytochrome c oxidase Vb gene. Gene Expr. 1995;5:93-111.

36. Carter RS, Avadhani NG. Cooperative binding of GA-binding protein transcription factors to duplicated transcription initiation region repeats of the cytochrome c oxidase subunit IV gene. J Biol Chem. 1994;269:4381-7.

37. Carter RS, Bhat NK, Basu A, Avadhani NG. The basal promoter elements of murine cytochrome $c$ oxidase subunit IV gene consist of tandemly duplicated ets motifs that bind to GABP-related transcription factors. J Biol Chem. 1992;267:23418-26.

38. Virbasius JV, Scarpulla RC. Activation of the human mitochondrial transcription factor a gene by nuclear respiratory factors: a potential regulatory link between nuclear and mitochondrial gene expression in organelle biogenesis. Proc Natl Acad Sci U S A. 1994:91:1309-13.

39. Villena JA, Vinas O, Mampel T, Iglesias R, Giralt M, Villarroya F. Regulation of mitochondrial biogenesis in brown adipose tissue: nuclear respiratory factor-2/GA-binding protein is responsible for the transcriptional regulation of the gene for the mitochondrial ATP synthase beta subunit. Biochem J. 1998;331:121-7.

40. Ouyang L, Jacob KK, Stanley FM. GABP mediates insulin-increased prolactin gene transcription. J Biol Chem. 1996; 271:10425-8.

41. Hoare S, Copland JA, Wood TG, Jeng YJ, Izban MG, Soloff MS. Identification of a GABP alpha/beta binding site involved in the induction of oxytocin receptor gene expression in human breast cells, potentiation by c-Fos/c-Jun. Endocrinology. 1999;140:2268-79. 